\title{
Malonomonas rubra gen. nov. sp. nov., a microaerotolerant anaerobic bacterium growing by decarboxylation of malonate
}

\author{
Irmtraut Dehning and Bernhard Schink \\ Lehrstuhl Mikrobiologie I, Eberhard-Karls-Universität, Morgenstelle 28, D-7400 Tübingen, Federal Republic of Germany
}

\begin{abstract}
From anoxic marine sediment samples, new anaerobic, microaerotolerant, Gram-negative, non-sporeforming bacteria were isolated which grew in mineral medium with malonate as sole source of carbon and energy. Cells were motile thin rods, often forming large aggregates. Malonate was decarboxylated to acetate with concomitant growth yields of $1.9-2.1 \mathrm{~g}$ dry cell matter per mol malonate degraded. Fumarate and malate were fermented to succinate and $\mathrm{CO}_{2}$. No other substrates were used. No inorganic electron acceptors were reduced. At least $150 \mathrm{mM} \mathrm{NaCl}$ was required for growth with either substrate. High amounts of a periplasmic cytochrome $c$ were detected, as well as small amounts of a membrane-bound cytochrome b. All enzymes of the citric acid cycle were found to be present. The DNA base ratio was $48.3 \mathrm{~mol} \%$ guanine plus cytosine. Since this new bacterium cannot be affiliated with any of the known genera and species, a new genus and species, Malonomonas rubra is proposed.
\end{abstract}

Key words: Malonomonas rubra species description - Malonic acid decarboxylation - Fumarate reduction - Bioenergetics

Anaerobic degradation of dicarboxylic acids as sole energy source has been reported for succinate (Schink and Pfennig 1982) and oxalate (Allison et al. 1985; Smith et al. 1985). These bacteria form ATP for growth from the small free energy change of the respective decarboxylation, reaction $\left(\Delta \mathrm{G}_{0}^{\prime}=\right.$ about $-20 \mathrm{~kJ} / \mathrm{mol}$; Thauer et al. 1977).

Propionigenium modestum which converts succinate to propionate conserves the decarboxylation energy in a $\mathrm{Na}^{+}$ion gradient across the membrane and synthesizes ATP by a $\mathrm{Na}^{+}$-dependent ATPase (Hilpert et al. 1984). The growth yield is $2.1-2.4 \mathrm{~g}$ dry cell matter per mol of succinate metabolized. Oxalobacter formigenes decarboxylates oxalate to formate and reaches a molar growth yield of $1.1 \mathrm{~g}$ dry cell matter. The mechanism of energy conservation in this bacterium has not yet been elucidated.

Offprint requests to: $\mathrm{I}$. Dehning
So far, two species of bacteria have been described which grow by decarboxylation of malonate to acetate, Sporomusa termitida (Breznak et al. 1988) and S. malonica (Dehning et al. 1989). In the present paper, a pure culture of a new anaerobe is described which is able to grow in mineral medium with malonate as sole source of carbon and energy, and differs basically from the above mentioned species.

\section{Materials and methods}

\section{Sources of isolates}

Two strains were enriched and isolated in pure culture from marine anoxic sediment samples: strain GraMal1 from mud of Canal Grande and strain TenMal1 from Rio del Tentor, both in Venice, Italy.

Enrichment cultures with freshwater medium were inoculated with anoxic sediment samples from polluted freshwater creeks near Marburg, and with anaerobic sludge from the municipal sewage treatment plant in Marburg, FRG.

\section{Media and growth conditions}

The mineral medium for enrichment and cultivation contained $30 \mathrm{mM}$ sodium bicarbonate buffer, $1 \mathrm{mM}$ sulfide as reducing agent, 7-vitamin solution (Widdel and Pfennig 1981), the trace element solution SL10, and selenite-tungstate solution (Widdel et al. 1983) and was prepared and dispensed as previously described (Widdel and Pfennig 1981; Schink and Pfennig 1982). The $\mathrm{pH}$ was adjusted to 7.2-7.3. Substrates were added from sterile stock solutions before inoculation. Growth of pure cultures were followed by measuring turbidity in $20 \mathrm{ml}$ screw-cap tubes in a Spectronic 20 spectrophotometer (Milton Roy Company, Rochester, NY, USA). Aerobic growth was tested in serum bottles with sulfide-free medium containing $0.3 \mathrm{mM}$ cystein under a $\mathrm{N}_{2}$ / $\mathrm{CO}_{2}(90 \% / 10 \%)$ gas phase to which $0.5-10 \% \quad \mathrm{O}_{2}$ was added. All growth experiments were carried out in duplicates at $30^{\circ} \mathrm{C}$. For further characterization, also a commercial media system (API 20A, BioMérieux, Nürtingen, FRG) was applied. 


\section{Isolation and cytological characterization}

Pure cultures were obtained by repeated application of the agar shake culture method (Pfennig and Trüper 1981). Purity was checked microscopically and by growth tests in complex medium (AC-medium, Difco-Laboratories, Detroit, MI, USA) with and without added malonate.

Gram staining was carried out according to Magee et al. (1975) with Acetobacterium woodii and Klebsiella sp. as controls. The KOH-test (Gregersen 1978) was applied in addition.

Flagella were stained as described by Blenden and Goldberg (1965).

\section{Chemical analyses}

Sulfide formation from sulfate, thiosulfate, or sulfur was analysed by the methylene blue method (Cline 1969). Formation of nitrite from nitrate was determined with sulfanilic acid and $\alpha$-naphthylamine according to Procházková (1959). Acetate and propionate were assayed by gas chromatography as described earlier (Dehning et al. 1989). Malonate, fumarate, and succinate were quantified in their methylated form (Metcalfe et al. 1966) by capillary gas chromatography (Carlo Erba Vega 6000, Milano, Italy). A $15 \mathrm{~m} / 0.32 \mathrm{~mm}$ capillary column with a $0.4 \mu \mathrm{m}$ layer of bonded and crosslinked Carbowax $20 \mathrm{M}$ was used. Column temperature was $140^{\circ} \mathrm{C}$, injector and detector temperature $180^{\circ} \mathrm{C}$, nitrogen flow rate $2 \mathrm{ml} / \mathrm{min} .2 \mu \mathrm{l}$ samples were injected into a split-splitless-injector with a split ratio of 1:50. To all samples and standards, oxalate was added as an internal standard.

Cytochromes were assayed in cell-free extracts as well as in membrane preparations obtained by ultracentrifugation $(1 \mathrm{~h}$ at $150000 \times g$ ). Redox difference spectra (dithionitereduced minus air-oxidized) were measured in an Uvikon 860 spectrophotometer (Kontron, Zürich, Switzerland). Cytochromes were identified by their typical absorption bands in crude cell extracts and in alkaline pyridine hemochrome extracts (Weston and Knowles 1973).

The DNA base composition was determined by thermal denaturation according to De Ley (1970) after extraction as described by Marmur (1961). Escherichia coli strain K12, DSM 498, was used as reference strain.

Protein was quantified by a modified microbiuret method (Zamenhoff 1957).

\section{Preparation of cell extracts}

All steps were performed at $4^{\circ} \mathrm{C}$ under a nitrogen gas atmosphere to maintain anaerobic conditions. Freshly harvested cells of the late exponential phase were resuspended in $3 \mathrm{ml}$ $50 \mathrm{mM}$ anoxic potassium phosphate buffer, $\mathrm{pH} 7.2$ and disrupted in a $\mathrm{N}_{2}$-flushed French press cell at 19000 psi $(131000 \mathrm{kPa})$. After microscopic control, the crude extract was directly used for enzymatic studies.

\section{Enzyme assays}

The assays were performed under anaerobic conditions in rubber-sealed nitrogen-gassed cuvettes $(1 \mathrm{ml})$ at $25^{\circ} \mathrm{C}$ using a Hitachi 100-40 spectrophotometer (Hitachi, Tokyo, Japan). All additions were made anoxically and injected into the cuvettes with microliter syringes.
Citrate synthase, NADP-dependent isocitrate dehydrogenase, phosphate acetyl transferase, and acetate kinase were measured by standard procedures (Bergmeyer 1974). NAD-dependent malate dehydrogenase and malic enzyme were assayed according to Stams et al. (1984). Succinate dehydrogenase was measured with potassium ferricyanide as electron acceptor (Stams et al. 1984) in the presence of $0.1 \mathrm{mM}$ phenazine methosulfate. 2-Oxoglutarate ferredoxin oxidoreductase with benzyl viologen as electron acceptor, acetyl-CoA synthetase, succinyl-CoA synthetase, and fumarase were assayed according to Brandis-Heep et al. (1983). Pyruvate synthase and fumarate reductase were measured with benzyl viologen after Odom and Peck (1981) and Boonstra et al. (1975), respectively. Isocitrate lyase and malate synthase were determined as described by Dixon and Kornberg (1959). ATP-Citrate lyase was assayed according to Möller et al. (1987). CO-dehydrogenase and hydrogenase (using $\mathrm{H}_{2}$ instead of $\mathrm{CO}$ ) were measured after Diekert and Thauer (1978). Succinyl-CoA: acetate CoA transferase was determined according to Hilpert et al. (1984) starting the reaction with $1 \mathrm{mM}$ acetate. Katalase and cytochrome-oxidase were assayed as described by Süßmuth et al. (1987). Oxaloacetate decarboxylase was measured as NADH-dependent lactate formation from oxaloacetate after Dimroth (1981). The washed membrane fraction for this assay was prepared by centrifugation for $1 \mathrm{~h}$ at $45000 \times g$.

\section{Chemicals}

All chemicals used were of analytical grade and obtained from Fluka, Neu-Ulm, or Merck, Darmstadt, FRG. Biochemicals were purchased from Boehringer, Mannheim, and Sigma, München, FRG.

\section{Results \\ Enrichment and isolation}

Fifty milliliter enrichment cultures with freshwater or salt water medium and $20 \mathrm{mM}$ di-sodium malonate were inoculated with $5 \mathrm{ml}$ anoxic mud from various habitats. Gas production started after 3-5 weeks indicating substrate degradation. In subcultures of the salt water enrichment cultures, turbidity developed within 2-4 weeks, but gas production decreased. After six transfers, cultures were subjected to two subsequent dilution series in agar medium with the same substrate.

Red, disc-shaped colonies appeared after 2 weeks of incubation. Two pure cultures were isolated (strains GraMal1 and TenMal1) which looked similar in the microscope. The cells were thin rods and degraded malonate to acetate. Strain GraMa11 was chosen for further characterization.

In the freshwater enrichment cultures, no further growth occurred after the fourth or fifth transfer. These cultures were not studied any further.

\section{Morphological and cytological properties}

Cells of strain GraMal1 were thin, straight to slightly curved rods with rounded ends, measuring $0.4 \times 3.1-4.0 \mu \mathrm{m}$ 


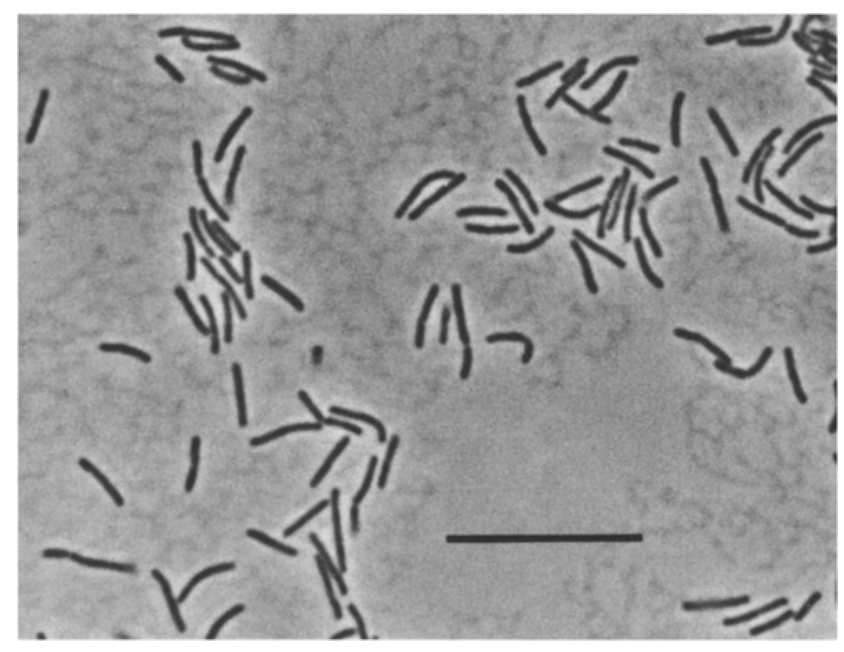

Fig. 1. Phase contrast photomicrograph of strain GraMal1 after growth in soft agar. Bar equals $10 \mu \mathrm{m}$

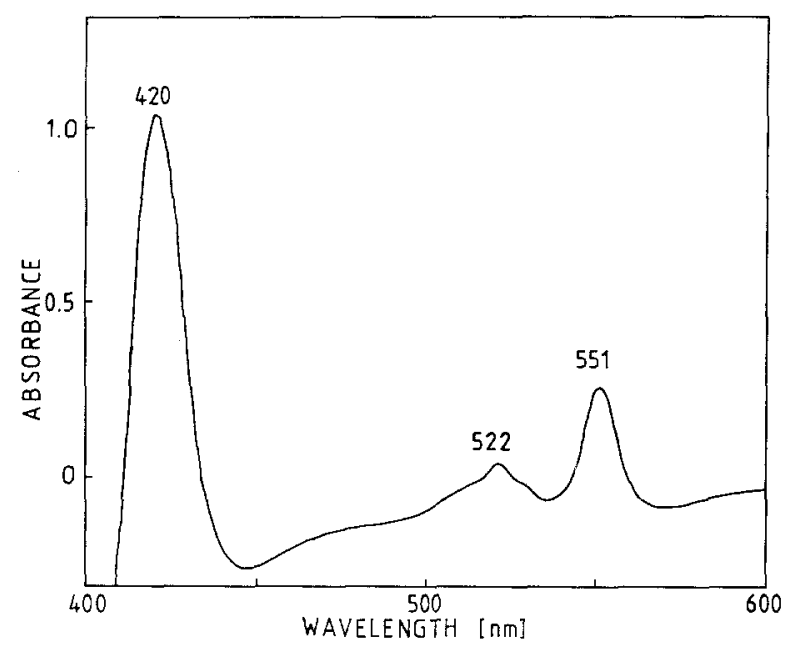

Fig. 2. Redox difference spectrum of crude cell-free extract of strain GraMal1. The cell extract contained $3.1 \mathrm{mg}$ protein $\mathrm{ml}^{-1}$

(Fig. 1). They occurred singly, in pairs, or sometimes in short chains. At the end of exponential growth, cells tended to form large aggregates which settled as clumps to the bottom of the culture vessel. Motility was observed in young cultures and flagella staining revealed $1-2$ polar flagella. The cells stained Gram-negative and also behaved Gram-negative in the KOH-test. Spores were never detected, even in the presence of soil extract, xylose, peptone, and manganese chloride. The guanine-plus-cytosine content of the DNA was $48.3 \pm 1.8 \mathrm{~mol} \%$.

In crude cell extracts, a cytochrome was found at very high concentration. From the absorption bands at 551, 522, and $420 \mathrm{~nm}$ it was identified as a c-type cytochrome (Fig. 2). Assuming a molecular weight of 12000 and an extinction coefficient for the $\alpha$-peak of $19.0 \mathrm{mM}^{-1} \mathrm{~cm}^{-1}$ (Chance and Williams 1955), a cytochrome c content of $60-80 \mathrm{mg}$ per $\mathrm{g}$ protein was calculated for the crude cell-free extract. Treatment of cell suspensions with lysozyme-EDTA in $0.3 \mathrm{M}$ sucrose solution revealed that the cytochrome was located in the periplasmic fraction. As marker enzyme of the cytoplasm malate dehydrogenase was used. The cytochrome could be incompletely reduced with ascorbic acid, indicating a redox potential in the range of $+50 \mathrm{mV}$. In acetone- $\mathrm{HCl}$ extracts of the membrane preparation, a small amount of cytochrome $b$ was detected with alkaline pyridine hemochrome absorption bands at 554, 519, and $419 \mathrm{~nm}$ (cytochrome c: 549,518 , and $414 \mathrm{~nm}$ ). The amounts of cytochromes were similar in malonate- and fumarate-grown cells, as well as under microaerobic conditions.

\section{Growth conditions and physiology}

Strain GraMal1 was not able to grow in freshwater medium. At least $150 \mathrm{mM} \mathrm{NaCl}$ or $100 \mathrm{mM} \mathrm{NaCl}$ plus $5 \mathrm{mM} \mathrm{MgCl}_{2}$ was required for growth. $\mathrm{NaCl}$ could not be replaced by $\mathrm{KCl}$. The salt requirements were the same with all growth substrates. Phosphate up to $50 \mathrm{mM}$ concentration did not influence growth. Yeast extract was not required, but enhanced growth rates and yields. Optimal growth occurred at $28-30^{\circ} \mathrm{C}$ and $\mathrm{pH} 7.1-7.3$. The temperature limits were 22 and $45^{\circ} \mathrm{C}$, the $\mathrm{pH}$ range was $6.0-8.5$.

Growth was also obtained under microaerobic conditions with $5 \% \mathrm{O}_{2}$ in the gas phase, however, growth was retarded and acetate was not utilized. The stoichiometries of malonate and fumarate degradation were the same as in the absence of oxygen. Catalase as well as cytochrome oxidase activity were both found under anaerobic and microaerobic conditions. Neither nitrate, nitrite, $\mathrm{N}_{2} \mathrm{O}$, nor sulfate, thiosulfate, sulfite, or sulfur was reduced. No growth occurred in ammonium-free medium with $\mathrm{N}_{2}$ in the gas phase.

Malonate, fumarate, and L-malate were the only substrates fermented by strain GraMal1 (Table 1). Methylmalonate did not serve as growth substrate, even in the presence of $2 \mathrm{mM}$ acetate, however, it was decarboxylated to propionate by resting cell suspensions. Malonate was decarboxylated to acetate; fumarate or malate were fermented to succinate and $\mathrm{CO}_{2}$. The stoichiometric relationships between substrate utilization, product formation, and synthesis of cell material are presented in Table 1. The molar growth yield with malonate was $1.9-2.1 \mathrm{~g}$ dry weight. The cell yield with fumarate $(10.8-11.4 \mathrm{~g} / \mathrm{mol})$ was not increased by addition of formate. The growth curves (Fig. 3) illustrate the correlation of growth, substrate decomposition, and product formation. The growth rate with malonate was $0.154 \mathrm{~h}^{-1}\left(t_{\mathrm{d}}=4.5 \mathrm{~h}\right)$ and with fumarate $0.192 \mathrm{~h}^{-1}\left(t_{\mathrm{d}}=3.6 \mathrm{~h}\right)$.

\section{Enzyme activities}

Enzymes were assayed in French press cell extracts prepared from malonate- or fumarate-grown cells of strain GraMal1. The activities did not differ significantly after growth with either substrate. The results are listed in Table 2. Most enzymes of the citric acid cycle were detected at high or moderate activities, except for fumarate reductase. The activity of oxaloacetate decarboxylase could not be measured reliably due to high background activities of chemical decarboxylation. Instead of succinyl-CoA synthetase, succinyl-CoA: acetate $\mathrm{CoA}$ transferase was detected. Acetate kinase and phosphate acetyl transferase were found at high amounts, whereas acetyl-CoA synthetase was present at only low activity. The activities of the enzymes of the glyoxylate cycle were in the range of $15 \mathrm{mU}$ per $\mathrm{mg}$ protein. Hydrogenase 
Table 1. Fermentation stoichiometry and growth yields of strain GraMal1

\begin{tabular}{|c|c|c|c|c|c|c|c|}
\hline \multirow[t]{2}{*}{ Substrate } & \multirow{2}{*}{$\begin{array}{l}\text { Substrate } \\
\text { degraded } \\
\text { (mmol) }\end{array}$} & \multirow{2}{*}{$\begin{array}{l}\text { Cell matter } \\
\text { formed } \\
(\mathrm{mg})^{\mathrm{a}}\end{array}$} & \multirow{2}{*}{$\begin{array}{l}\text { Substrate } \\
\text { assimilated } \\
(\mathrm{mmol})^{\mathrm{b}}\end{array}$} & \multicolumn{2}{|c|}{ Products formed (mmol) } & \multirow{2}{*}{$\begin{array}{l}\text { Electron } \\
\text { recovery }(\%)\end{array}$} & \multirow{2}{*}{$\begin{array}{l}\text { Growth yield } \\
\text { (mg/mmol sub- } \\
\text { strate utilized) }\end{array}$} \\
\hline & & & & Acetate & Succinate & & \\
\hline Malonate & 11.8 & 24.0 & 0.5 & 11,1 & 0.1 & 98.9 & 2.0 \\
\hline Fumarate & 4.3 & 47.1 & 0.65 & - & 3.2 & 101.7 & 10.9 \\
\hline Malate & 5.2 & 50.4 & 0.7 & - & 3.7 & 96.3 & 9.7 \\
\hline
\end{tabular}

Experiments were carried out in $500 \mathrm{ml}$ serum bottles. All figures are means of at least two independent assays.

${ }^{\text {a }}$ Cell dry weights were determined directly in $500 \mathrm{ml}$ cultures

${ }^{b}$ Assimilation of substrates into cell material was calculated as follows:

malonate: $17 \mathrm{C}_{3} \mathrm{H}_{4} \mathrm{O}_{4} \rightarrow 8\left\langle\mathrm{C}_{4} \mathrm{H}_{7} \mathrm{O}_{3}\right\rangle+19 \mathrm{CO}_{2}+6 \mathrm{H}_{2} \mathrm{O}$

fumarate: $17 \mathrm{C}_{4} \mathrm{H}_{4} \mathrm{O}_{4}+8 \mathrm{H}_{2} \mathrm{O} \rightarrow 12\left\langle\mathrm{C}_{4} \mathrm{H}_{7} \mathrm{O}_{3}\right\rangle+20 \mathrm{CO}_{2}$

malate: $\quad 17 \mathrm{C}_{4} \mathrm{H}_{6} \mathrm{O}_{5} \rightarrow 12\left\langle\mathrm{C}_{4} \mathrm{H}_{7} \mathrm{O}_{7}\right\rangle+20 \mathrm{CO}_{2}+9 \mathrm{H}_{2} \mathrm{O}$

Substrates not utilized: formate, oxalate, maleinate, succinate, glutarate, adipate (all in the presence of $2 \mathrm{mM}$ acetate); glycolate, glyoxylate, lactate, pyruvate, oxaloacetate, citrate, L-aspartate, glycin, glycerol, ethylene glycol, acetoin, methanol, ethanol, fructose, glucose, arabinose, xylose, peptone, casamino acids

was detected at very low activity. No CO-dehydrogenase and ATP-Citrate lyase were found.

\section{Discussion}

Physiology

The new anaerobic bacterium described in this study was enriched and isolated in defined salt water medium with malonate as sole carbon and energy source. Malonate was decarboxylated to acetate:

$\mathrm{C}_{3} \mathrm{H}_{2} \mathrm{O}_{4}^{2-}+\mathrm{H}_{2} \mathrm{O} \rightarrow \mathrm{C}_{2} \mathrm{H}_{3} \mathrm{O}_{2}^{-}+\mathrm{HCO}_{3}^{-}$

$\Delta \mathrm{G}_{0}^{\prime}=-17.4 \mathrm{~kJ} / \mathrm{mol}$.

This reaction obviously supplied enough energy to support the whole energy metabolism of this bacterium. The small free energy change (1) (calculated after Thauer et al. 1977) does not allow substrate-linked phosphorylation, and no redox reactions occur which could drive electron transport phosphorylation for ATP synthesis. The phenomenon that bacteria can grow by decarboxylation of dicarboxylic acids only, has already been described for Propionigenium modestum (Schink and Pfennig 1982) degrading succinate, and for Oxalobacter formigenes (Allison et al. 1985) growing with oxalate. The low growth yields of $1.9-2.1 \mathrm{~g}$ dry cell matter per mol malonate metabolized by strain GraMal1 and $2.1-2.4 \mathrm{~g}$ per mol succinate with $P$. modestum are in the same range and reflect the small change of free energy connected to the decarboxylation reactions. The growth yield of $1.1 \mathrm{~g}$ dry cell matter per mol oxalate utilized by $O$. formigenes is even lower.

In $P$. modestum, a membrane-bound methylmalonylCoA decarboxylase converts the decarboxylation energy into a sodium ion gradient (Hilpert et al. 1984). This organism contains a sodium ion-dependent ATPase for ATP synthesis. The dependence of strain GraMal1 on $\mathrm{NaCl}$ indicates that a similar way of energy conservation may be involved. Further studies on this subject are in progress in our laboratory.

Strain GraMal1 is also able to ferment fumarate (malate) to succinate and $\mathrm{CO}_{2}$ :

$$
\begin{aligned}
& 7 \mathrm{C}_{4} \mathrm{H}_{2} \mathrm{O}_{4}^{2-}+8 \mathrm{H}_{2} \mathrm{O} \rightarrow 6 \mathrm{C}_{4} \mathrm{H}_{4} \mathrm{O}_{4}^{2-}+4 \mathrm{HCO}_{3}^{-}+2 \mathrm{H}^{+} \\
& \Delta \mathrm{G}_{0}^{\prime}=-65.8 \mathrm{~kJ} / \text { mol fumarate }
\end{aligned}
$$

The pathway involved is probably analogous to that of Proteus rettgeri (Kröger 1974). One mol of fumarate is oxidized via oxaloacetate to $2 \mathrm{CO}_{2}$ and acetyl-CoA which condenses to citrate with oxaloacetate formed from a second mol of fumarate. Citrate is metabolized to succinate and $2 \mathrm{CO}_{2}$ through most of the citric acid cycle reactions. The resulting 10 reducing equivalents reduce further $5 \mathrm{~mol}$ of fumarate to succinate (Fig. 4). All measured enzymes of the citric acid cycle showed sufficient activities for the energy metabolism of strain GraMal1. The comparably low detected activity of fumarate reductase may be due to improper assay conditions of this membrane-bound enzyme. The small amount of cytochrome $b$ found could serve as redox carrier in the fumarate reductase reaction.

Per $7 \mathrm{~mol}$ of fumarate consumed, $1 \mathrm{~mol} \mathrm{ATP}$ can be formed by substrate-level phosphorylation (probably via acetate kinase instead of succinyl-CoA synthetase), and at maximum $5 \mathrm{~mol}$ ATP by electron transport phosphorylation via fumarate reduction (Fig. 4). Stouthamer (1979) calculated a mean energy yield coefficient of $10 \mathrm{~g}$ cell dry matter per mol ATP for anaerobes growing in a defined mineral medium. Our measured growth yield of about $70 \mathrm{~g}$ per total reaction (2) is in good agreement with this calculation, assuming $6 \mathrm{~mol}$ ATP to be formed per reaction (2). The synthesis of $1 \mathrm{~mol}$ ATP requires under physiological conditions between 60 and $80 \mathrm{~kJ}$ (Thauer et al. 1977). The free energy change of $-460.6 \mathrm{~kJ}$ of the whole reaction (2) would allow the synthesis of $6-7 \mathrm{~mol}$ ATP which again supports the energy balance outlined above.

The enzymes of the citric acid cycle were also found at comparable activities in extracts of cells grown with malonate. This is surprising at first sight, however, may be explained by a possible function in the assimilatory metabolism. Malonate is converted to acetate, and acetate assimilation to sugars requires reducing equivalents, mainly for the pyruvate synthase and the glyceraldehyde-3-phosphate dehydrogenase reaction. These reducing equivalents could be provided by acetate oxidation in the citric acid cycle. 

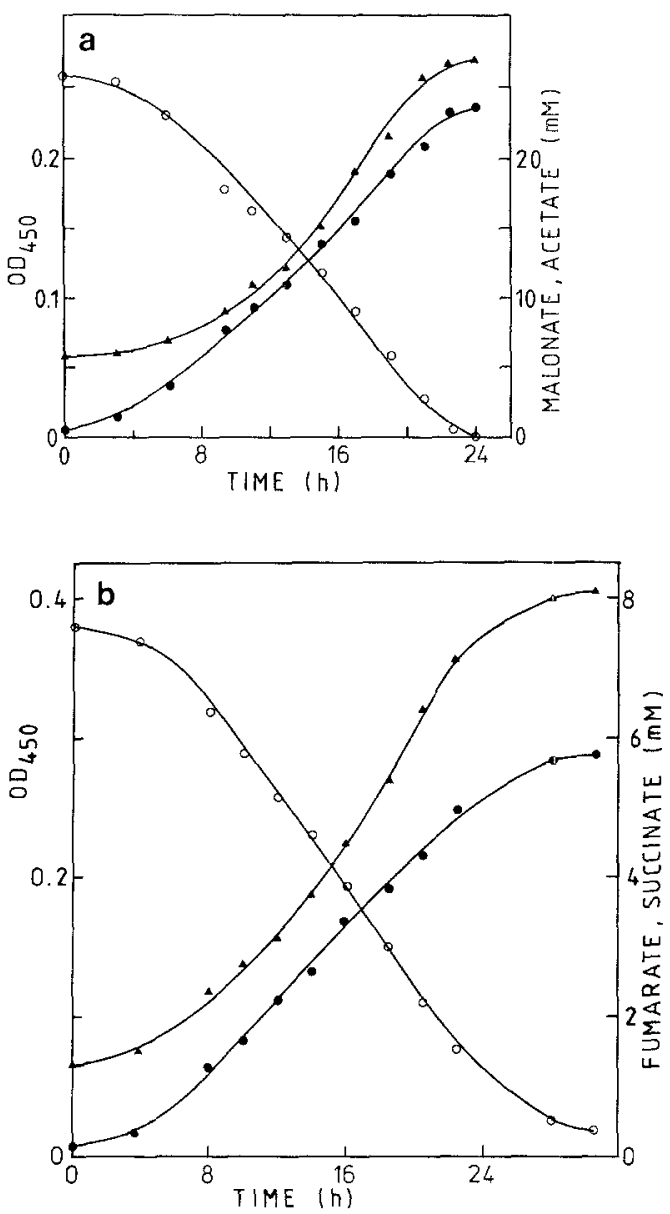

Fig. 3a, b. Fermentation time courses of strain GraMal1 in mineral medium with malonate or fumarate as substrate. Experiments were performed at $30^{\circ} \mathrm{C}$ in $130 \mathrm{ml}$ serum bottles. Samples were removed by a syringe, and the headspaces were flushed with $\mathrm{N}_{2} / \mathrm{CO}_{2}$ gas mixture. $\mathrm{OD}_{450}$ : optical density at $450 \mathrm{~nm}$. Symbols: $\Delta$ cell density; a $\bigcirc$ malonate, acetate; b $\bigcirc$ fumarate, succinate

The presence of high amount of cytochrome $\mathrm{c}$ in the anaerobic, microaerotolerant strain GraMal1 is not yet understood. Perhaps it functions in protection against oxygen, or represents part of an incomplete respiratory chain. We could not find an electron acceptor for this cytochrome system yet. Perhaps our isolate could even oxidize acetate to $\mathrm{CO}_{2}$ via its citric acid cycle enzymes if a suited electron acceptor could be provided. The enzymes of the glyoxylate cycle for the assimilatory metabolism of acetate were present in sufficient activities.

\section{Taxonomy}

So far no bacteria were described which were physiologically, morphologically, or cytologically similar to our new isolates and could grow by decarboxylation of malonate as sole source of energy. Strain GraMal1 cannot be affiliated with the genus Sporomusa, because it had no acetogenic metabolism and did not sporulate. The isolate can neither be assigned to the genus Propionigenium, because of its considerably higher $\mathrm{G}+\mathrm{C}$ content of the DNA and its basically different physiology. Although the new isolate has the same $\mathrm{G}+\mathrm{C}$ content as Oxalobacter, its ability to grow with
Table 2. Specific activities of enzymes detected in crude extracts of cells of strain GraMal1 grown with fumarate and malonate

\begin{tabular}{|c|c|c|}
\hline Enzyme & $\begin{array}{l}\mathrm{EC} \\
\text { number }\end{array}$ & $\begin{array}{l}\text { Specific activity } \\
\left(\mu \mathrm{mol} \times \min ^{-1}\right. \\
\left.\times \mathrm{mg}^{-1} \text { protein }^{-1}\right)\end{array}$ \\
\hline Citrate synthase & 4.1.3.7 & 1.6 \\
\hline ATP-Citrate lyase & 4.1.3.8 & 0.003 \\
\hline $\begin{array}{l}\text { Isocitrate dehydrogenase, } \\
\text { NADP-dependent }\end{array}$ & 1.1.1.41 & 2.4 \\
\hline $\begin{array}{l}\text { 2-Oxoglutarate ferredoxin } \\
\text { oxidoreductase }^{\mathrm{a}}\end{array}$ & 1.2.7.3 & 0.086 \\
\hline Succinyl-CoA synthetase & 6.2 .1 .5 & 0.006 \\
\hline Succinyl-CoA:acetate & & \\
\hline CoA transferase & - & 0.075 \\
\hline Succinate dehydrogenase ${ }^{c}$ & 1.3 .99 .1 & 0.43 \\
\hline Fumarate reductase $\mathrm{b}^{\mathrm{b}}$ & 1.3 .1 .6 & 0.012 \\
\hline Fumarase & 4.2.1.2 & 8.2 \\
\hline $\begin{array}{l}\text { Malate dehydrogenase, } \\
\text { NAD-dependent }\end{array}$ & 1.1.1.37 & 2.1 \\
\hline Malic enzyme & 1.1.1.38? & 0.015 \\
\hline Pyruvate synthase $^{\text {a }}$ & 1.2 .7 .1 & 0.078 \\
\hline Acetate kinase & 2.7 .2 .1 & 0.65 \\
\hline Phosphate acetyl transferase & 2.3.1.8 & 1.1 \\
\hline Acetyl-CoA synthetase & 6.2.1.1 & 0.018 \\
\hline Isocitrate lyase & 4.1.3.1 & 0.013 \\
\hline Malate synthase & 4.1 .3 .2 & 0.016 \\
\hline Hydrogenase $^{\mathrm{a}}$ & 1.18 .99 .1 & 0.014 \\
\hline CO-dehydrogenase ${ }^{b}$ & 1.2 .99 .2 & 0.001 \\
\hline
\end{tabular}

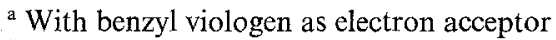

${ }^{b}$ With benzyl viologen as electron donor

c With potassium ferricyanide as electron acceptor in the presence of phenazine methosulfate

${ }^{d}$ After International Union of Biochemistry (1984)

Assays were performed under anaerobic conditions as described in Materials and methods. $10-200 \mu \mathrm{g}$ protein were applied per assay. All figures are means of $2-4$ independent experiments with a variation of $10-20 \%$. Fumarate reductase asayed in fresh cell suspensions permeabilized with cetyltrimethylammonium bromide or with Triton-X-100 showed similar activities

malonate and fumarate, its microaerotolerance, and the different morphology exclude it from this genus. Therefore, it appears necessary to establish a new genus and species for the described isolate.

Genus Malonomonas gen. nov. Ma.lo.no.mo'nas. M.L.n. acidum malonicum malonic acid; Gr.f.n. monas a monad or unit; Malonomonas M.L.f.n. a malonic acid utilizing monad.

Only existing species so far: $M$. rubra. Genus description so far identical with species description.

\section{Species description}

Malonomonas rubra sp. nov. ru'bra. L.adj. ruber red; rubra f., referring to the red colour of the cells.

Straight to slightly curved rods with rounded ends, $0.4 \times 3.1-4.0 \mu \mathrm{m}$ in size, singly, in pairs, short chains, or large aggregates. Motile in young cultures by polar flagella. Gram-negative, non-sporeforming.

Microaerotolerant anaerobic chemoorganotroph. Malonate decarboxylated to acetate, fumarate or malate fermented to succinate and $\mathrm{CO}_{2}$. No other organic acids, sugars, or alcohols utilized. Neither nitrate, $\mathrm{N}_{2} \mathrm{O}$, sulfate, thiosulfate, sulfite, nor sulfur reduced. No $\mathrm{N}_{2}$-fixation. Growth in min- 


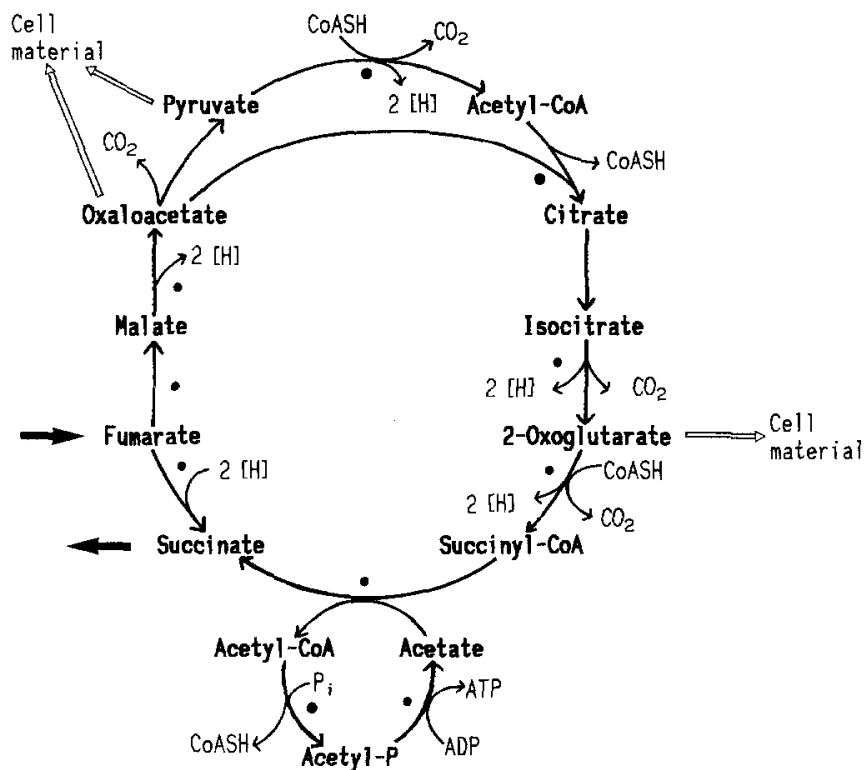

Fig. 4. Hypothetical pathway of fumarate fermentation by strain GraMal1. enzymes detected (cf. Table 2)

eral medium requires at least $150 \mathrm{mM} \mathrm{NaCl}$. Indole not formed, gelatin, urea, or esculin not hydrolyzed; weak catalase and cytochrome oxidase activity.

Selective enrichment in salt water medium with malonate as substrate. $\mathrm{pH}$ range: $6.0-8.5$, optimum at $7.1-7.3$. Temperature range: $22-45^{\circ} \mathrm{C}$, optimum at $28-30^{\circ} \mathrm{C}$. High amounts of periplasmic cytochrome $\mathrm{c}$, small amounts of membrane-bound cytochrome b. DNA base ratio: 48.3 $\pm 1.8 \mathrm{~mol} \%$ (thermal denaturation). Habitat: anoxic mud of marine origin. Type strain: GraMal1, DSM 5091; deposited in Deutsche Sammlung von Mikroorganismen, Braunschweig, FRG.

Acknowledgements. This study was supported by grants of the Deutsche Forschungsgemeinschaft.

\section{References}

Allison MJ, Dawson KA, Mayberry WR, Foss JG (1985) Oxalobacter formigenes gen. nov., sp. nov.: oxalate-degrading anaerobes that inhabit the gastrointestinal tract. Arch Microbiol 141:1-7

Bergmeyer HU (1974) Methoden der enzymatischen Analyse, 3rd ed. Verlag Chemie, Weinheim, FRG

Blenden DC, Goldberg HS (1965) Silver impregnation stain for Leptospira and flagella. J Bacteriol 89:899-900

Boonstra J, Huttunen MT, Konings WN, Kaback HR (1975) Anaerobic transport in Escherichia coli membrane vesicles. J Biol Chem 250:6792-6798

Brandis-Heep A, Gebhardt NA, Thauer RK, Widdel F, Pfennig N (1983) Anaerobic acetate oxidation to $\mathrm{CO}_{2}$ by Desulfobacter postgatei. 1. Demonstration of all enzymes required for the operation of the citric acid cycle. Arch Microbiol 136:222-229

Breznak JA, Switzer JM, Seitz H-J (1988) Sporomusa termitida sp. nov, an $\mathrm{H}_{2} / \mathrm{CO}_{2}$-utilizing acetogen isolated from termites. Arch Microbiol 150:282-288

Chance B, Williams GR (1955) Respiratory enzymes in oxidative phosphorylation. II. Difference spectra. J Biol Chem 217:395407

Cline JD (1969) Spectrophotometric determination of hydrogen sulfide in natural waters. Limnol Oceanogr 14:454-458
Dehning I, Stieb M, Schink B (1989) Sporomusa malonica sp. nov, a homoacetogenic bacterium growing by decarboxylation of malonate and succinate. Arch Microbiol 151:421-426

De Ley J (1970) Reexamination of the association between melting point, buoyant density and the chemical base composition of deoxyribonucleic acid. J Bacteriol 101:738-754

Diekert G, Thauer RK (1978) Carbon monoxide oxidation by Clostridium thermoaceticum and C. formicoaceticum. J Bacteriol 136:597-606

Dimroth P (1981) Characterization of a membrane-bound biotincontaining enzyme: oxaloacetate decarboxylase from Klebsiella aerogenes. Eur J Biochem 115:353-358

Dixon GH, Kornberg HL (1959) Assay methods for key enzymes of the glyoxylate cycle. Biochem J 72:3P

Gregersen T (1978) Rapid method for distinction of Gram-negative from Gram-positive bacteria. Eur $\mathbf{J}$ Appl Microbiol Biotechnol $5: 123-127$

Hilpert W, Schink B, Dimroth P (1984) Life by a new decarboxylation-dependent energy conservation mechanism with $\mathrm{Na}^{+}$as coupling ion. EMBO J 3:1665-1670

International Union of Biochemistry (ed) (1984) Enzyme nomenclature 1984. Academic Press, New York

Kröger A (1974) Electron-transport phosphorylation coupled to fumarate reduction in anaerobically grown Proteus rettgeri. Biochim Biophys Acta 347:273-289

Magee CM, Rodeheaver G, Edgerton MT, Edlich RF (1975) A more reliable Gram staining technic for diagnosis of surgical infections. Am J Surg 130:341 - 346

Marmur J (1961) A procedure for the isolation of deoxyribonucleic acid from microorganisms. J Mol Biol 3:208-218

Metcalfe LD, Schmitz AA, Pelka JR (1966) Rapid preparation of fatty acid esters from lipids for gaschromatographic analysis. Anal Chem 38:514-515

Möller D, Schauder R, Fuchs G, Thauer RK (1987) Acetate oxidation to $\mathrm{CO}_{2}$ via a citric acid cycle involving an ATP-citrate lyase: a mechanism for the synthesis of ATP via substrate level phosphorylation in Desulfobacter postgatei growing on acetate and sulfate. Arch Microbiol 148:202-207

Odom JM, Peck HD (1981) Localization of dehydrogenases, reductases and electron transfer components in the sulfate-reducing bacterium Desulfovibrio gigas. J Bacteriol 147:161-169

Pfennig N, Trüper HG (1981) Isolation of members of the families Chromatiaceae and Chlorobiaceae. In: Starr MP, Stolp $\mathrm{H}$, Trüper HG, Balows A, Schlegel HG (eds) The prokaryotes, vol I. Springer, Berlin Heidelberg New York, pp 279-289

Procházková L (1959) Bestimmung der Nitrate im Wasser. Z Anal Chem 167:254-260

Schink B, Pfennig N (1982) Propionigenium modestum gen. nov. sp. nov., a new strictly anaerobic, nonsporing bacterium growing on succinate. Arch Microbiol 133:209-216

Smith RL, Strohmaier FE, Oremland RS (1985) Isolation of anaerobic oxalate-degrading bacteria from freshwater lake sediments. Arch Microbiol 141:8-13

Stams AJM, Kremer DR, Nicolay K, Weenk GH, Hansen TA (1984) Pathway of propionate formation in Desulfobulbus propionicus. Arch Microbiol 139:167-173

Stouthamer AG (1979) The search for correlation between theoretical and experimental growth yields. In: Quayle JR (ed) International review of biochemistry, microbial biochemistry, vol 21. University Park Press, Baltimore, pp $1-47$

Süßmuth R, Eberspächer J, Haag R, Springer W (1987) Biochemisch-mikrobiologisches Praktikum. Georg Thieme Verlag, Stuttgart

Thauer RK, Jungermann K, Decker K (1977) Energy conservation of chemotrophic anacrobic bacteria. Bacteriol Rey 41:100180

Weston JA, Knowles CJ (1973) A soluble CO-binding c-type cytochrome from the marine bacterium Beneckea natriegens. Biochim Biophys Acta 305:11-18

Widdel F, Pfennig N (1981) Studies on dissimilatory sulfate-reducing bacteria that decompose fatty acids. I. Isolation of a new 
sulfate-reducer enriched with acetate from saline environments. Description of Desulfobacter postgatei gen. nov. sp. nov. Arch Microbiol 129:395-400

Widdel F, Kohring GW, Mayer F (1983) Studies on dissimilatory sulfate-reducing bacteria that decompose fatty acids. III, Characterization of the filamentous gliding Desulfonema limicola gen. nov. sp. nov., and Desulfonema magnum sp. nov. Arch Microbiol 134:286-294
Zamenhoff S (1957) Preparation and assay of deoxyribonucleic acid from animal tissue. In: Methods in enzymology, vol 3, Colowick SP, Kaplan NO (eds), Academic Press, New York, pp 696-704

Received October 17, 1988/Accepted January 15, 1989 